\title{
KAIDAH MORFOFONEMIK BAHASA SUMBAWA DIALEK SUMBAWA BESAR
}

\author{
Rahmad Hidayat \\ Universitas Mataram \\ Pos-el: rahmad_ab@unram.ac.id
}

\begin{abstract}
A bstrak
Penelitian ini bertujuan mendeskripsikan kaidah morfofonemik bahasa Sumbawa dialek Sumbawa Besar. Uraian proses morfofonemik dalam penelitian ini berfokus pada kaidah morfofonemik berdasarkan seluruh kelompok morfem afiks yang terdapat dalam bahasa Sumbawa dialek Sumbawa Besar. Pengumpulan data dilakukan dengan metode instrospektif dan teknik catat. Penganalisisan data menggunakan teknik hubung-banding menyamakan dan hubung-banding membedakan dari metode padan intralingual. Penyajian hasil analisis data menggunakan metode formal dan informal. Morfem afiks dalam BSDSB terdiri atas prefiks yakni $\{\mathrm{ba}-\},\{r a N-\},\{k a-\},\{k a N-\},\{\mathrm{pa}-\},\{\mathrm{paN}-\},\{\mathrm{sa}-\},\{\mathrm{saN}-\}$, dan $\mathbb{N}-\}$ serta infiks $\{\mathrm{N}-\}$. Tiap-tiap morfem afiks memiliki beberapa wujud konkret berupa morf ketika bergabung dengan bentuk dasar melalui afiksasi. Morfem \{ba-\}memiliki empat wujud konkret, yaitu \{ba-\}, \{bar-\}, \{bal-\}, dan $\{r a-\}$. Morfem $\{r a N-\}$ memiliki empat wujud konkret berupa $\{r a n-\},\{r a m-\},\{r a \eta-\}$, dan $\{r a n ̃-\}$. Morfem \{ka-\} hanya memiliki satu wujud konket, yaitu \{ka-\}. Morfem $\{k a N-\}$ memiliki tujuh wujud konkret, yaitu $\{k a-\},\{k a \eta-\},\{k a m-\},\{k a n-\},\{k a n ̃-\},\{k a \eta \partial-\}$, dan fgan-\}. Morfem \{saN-\}

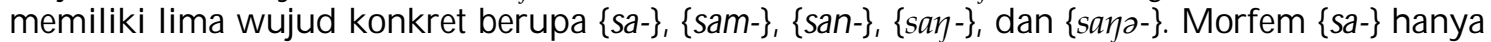
memiliki satu wujud konkret yakni \{sa-\}. Morfem \{pa-\} hanya memiliki wujud konkret berupa

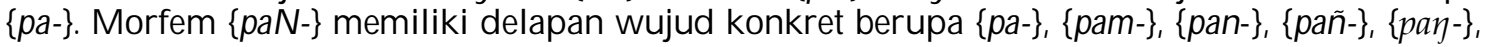
$\{$ payz- $\}$, \{par-\}, dan \{pal-\}. Morfem $\mathbb{N}-\}$ memiliki enam wujud konkret berupa morf $\{\hat{\{}-\},\{\mathfrak{n}-\},\{m-\}$, $\{n-\},\{m a\}$, dan $\{$ mar- $\}$. Morfem infiks $\{-\mathrm{N}-\}$ memiliki dua wujud konkret berupa $\{-n-\}$ dan $\{m-\}$.
\end{abstract}

Kata kunci: Kaidah, Proses Morfofonemik, Bahasa Sumbawa Dial ek Sumbawa Besar

\begin{abstract}
This study aimed to describe morphophonemic rules of Sumbawa language of Sumbawa Besar dial ect. The description of the morphophonemic process in this study focuses on the morphophonemic rules based on the entire group of affixed morphemes found in the Sumbawa language of Sumbawa Besar dialect. The data was collected by using Introspektif method and Catat technique. A nalyzing data using the $\mathrm{H}$ ubungBanding Menyamakan and $\mathrm{Hubung}$-Banding $\mathrm{M}$ embedakan techniques of the Padan Intralingual methods. The presentation of data analysis results using Formal and Informal methods. The affixed morpheme in BSD SB consists of prefixes $\{\mathrm{ba}-\},\{\mathrm{raN}-\},\{\mathrm{ka}-\},\{\mathrm{kaN}-\},\{\mathrm{pa}-\},\{\mathrm{paN}-\},\{\mathrm{sa}-\},\{\mathrm{saN}-\}$, and $\{\mathrm{N}-\}$ and infix $\{-\mathrm{N}-\}$. Each affixed morpheme has several concrete forms of morph as it joins the basic form by affixation. $M$ orpheme $\{$ ba- $\}$ has four concrete forms, namely $\{$ ba- $\},\{$ bar- $\}$, $\{$ bal- $\}$, and $\{r a-\}$. M orpheme $\{r a N-\}$ has four concrete forms, they are $\{r a n-\},\{r a m-\},\{r a \eta-\}$, and $\{r a n ̃-\} . M$ orpheme $\{k a-\}$ has only a concrete form of $\{\mathrm{ka}-\}$. M orpheme $\{\mathrm{kaN}-\}$ has seven concrete forms, namely $\{\mathrm{ka}-\},\{k a \eta-\},\{k a m-\},\{\mathrm{kan}-\}$, $\{k a n ̃-\},\{k a \eta \jmath-\}$, and $\{$ gan- $\}$. M orpheme $\{$ saN -$\}$ has five concrete forms, they are $\{$ sa- $\},\{$ sam- $\}$, \{san- $\},\{$ san- $\}$, and \{say- $\}$. M orpheme $\{$ sa- $\}$ has only a concrete form of $\{s-\}$. M orpheme $\{p a-\}$ has only a concrete form of

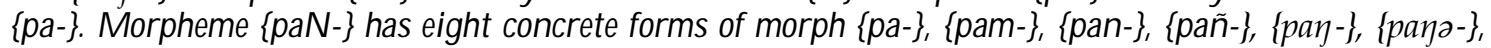
$\{$ par- $\}$, and $\{$ pal- $\}$. M orpheme $\{N-\}$ has six concrete forms of morph $\{\eta-\},\{\tilde{n}-\},\{m-\},\{n-\},\{m a\}$, and $\{m a r-\}$. Infix morpheme $\{-\mathrm{N}-\}$ has two concrete forms of morph $\{-n-\}$ and $\{-m-\}$.
\end{abstract}

Keyw ords: Rules, M orphophonemic P rocess, Sumbawa Language of Sumbawa Besar D ial ect 


\section{PEN DAHULUAN}

Proses morfofonemik-sebagian ahli menyebut proses morfofonologi-merupakan proses yang menyuratkan kaitan antara subsistem fonologi dan subsistem morfologi pada level afiksasi. Dalam hal ini, fonologi merupakan wujud utama yang disorot sebagai akibat persinggungan morfem. Beberapa ahli berbeda pendapat mengenai penggolongan akibat persinggungan morfem ini. Hal ini terjadi karena para ahli tersebut berbeda pandangan dalam menentukan lambang morfem.

Ramlan (2012: 85) memilih bentuk \{meN-\} sebagai lambang morfem. Berbeda dengan Ramlan, Chaer (2008: 43) memilih \{me- sebagai lambang morfem. Pada kasus yang sama, morfem \{meN-\}dan \{me-\}memperlihatkan perbedaan penggolongan akibat persinggungan morfem. Ramlan menyebut $\{\mathrm{meN}-\}+$ bantu menjadi membantu merupakan akibat persinggungan morfem yang berupa perubahan fonem, sedangkan Chaer menganggap $\{\mathrm{me}$ - + baca menjadi membaca sebagai akibat persinggungan morfem yang berupa pemunculan fonem. Perbedaan ini, disebabkan oleh perbedaan lambang morfem yang dipilih oleh tiap-tiap ahli.

Tulisan ini berfokus pada pemaparan kaidah proses morfofonomik dibandingkan pengklasifikasian kaidah akibat persinggungan morfem. Namun, pengklasifikasian tetap dilakukan berdasarkan kelompok morfem afiks. Kaidah proses morfofonemik yang dibahas dalam tulisan ini adalah kaidah proses morfofonemik Bahasa Sumbawa Dialek Sumbawa Besar (selanjutnya disingkat BSDSB).

BSDSB merupakan salah satu dialek bahasa Sumbawa yang terdapat di wilayah Kabupaten Sumbawa, Provinsi Nusa Tenggara Barat. BSDSB merupakan dialek standar di antara beberapa dialek lainnya dalam bahasa Sumbawa, yakni dialek Tongo, dialek Jereweh, dan dialek Taliwang (lihat Mahsun, 2007: 48). Secara umum, bahasa ini hanya memiliki afiks yang berupa prefiks dan infiks. Infiksnya pun tidak produk- tif. Pelbagai proses penggabungan afiks hanya dapat dilakukan dengan memadukan prefiks dengan prefiks. Prefiks menanggung beban makna yang relatif berat dalam afiksasi bahasa ini. Prefiks-prefiks yang terdapat dalam BSDSB adalah $\{$ ba- $\},\{$ raN -$\},\{$ pa- $\},\{k a N-\},\{p a-\},\{p a N-\}$, $\{$ sa- $\}$, $\{$ saN -$\}$, dan $\{\mathrm{N}-\}$, sedangkan infiks hanya berupa $\{\mathrm{N}-\}$.

Kaidah proses morfofonemik dalam BSDSB tergolong unik karena menyuratkan berbagai wujud konkret lambang morfem yang disebut morf. Morf-morf yang muncul terkadang jauh berbeda bentuk dari lambang morfemnya. Misalnya, morfem \{ba- $\}$ yang memiliki berbagai wujud konkret berupa $\{$ ba- $\}$, \{bar-\}, \{bal-\}, dan $\{$ ra- $\}$. Selain itu, terdapat juga morfem $\mathbb{N}$ - $\}$ yang memiliki wujud konkret berupa $\{n-\},\{m-\},\{\eta-\}$, $\{\tilde{n}-\},\{$ ma- $\}$, dan $\{$ mar- $\}$. Tak terkecuali juga de ngan morfem \{kaN \}yang memiliki wujud konkret berupa $\{\mathrm{gaN}-$ \}.

Penelitian terkait proses morfofonemik dalam bahasa Sumbawa telah dilakukan oleh beberapa peneliti. Di antaranya adalah penelitian yang dilakukan oleh Mahsun (1990) dan Kasman (2008). Mahsun meneliti morfologi bahasa Sumbawa dialek Jereweh, dan Kasman (2008) meneliti morfologi dan morfofonemik bahasa Sumbawa dialek Tongo. Dialek yang diteliti tersebut berbeda dengan dialek yang diteliti dalam penelitian ini, dan cukup menyuratkan perbedaan terutama pada jenis-jenis afiks.

Penelitian mengenai BSDSB juga menyinggung proses morfofonemik tetapi tidak tersurat disebutkan adalah penelitian yang dilakukan oleh Sumarsono dkk. (1986) dan Seken dkk. (1990). Kekurangan penelitian yang dilakukan oleh Sumarsono dkk. (1986) dan Seken dkk. (1990) telah disampaikan oleh Mahsun (periksa Hidayat, 2014: 11-13). Penelitian Sumarsono tidak membahas proses morfofonemik BSDSB dalam kajiannya serta tidak mengklasifikasikan afiks-afiks dalam BSDSB berdasarkan korelasi bentuk dan makna. Penelitian Seken dkk. yang lebih fokus membahas kajian morfologi telah mencantumkan pembahasan proses morfo- 
fonemik. Akan tetapi, pengklasifikasian afiksafikstidak dilakukan sebagaimanayang dilakukan oleh Sumarsono dkk.

Penelitian yang secara khusus membahas proses morfofonemik BSDSB telah dilakukan oleh peneliti dalam bentuk skripsi (periksa Hidayat, 2011). Dalam penelitian tersebut, peneliti belum mengelompokkan afiks berdasarkan korelasi bentuk dan maknanya. Untuk itu, kekurangan dan keal paan yang terdapat dalam penelitian sebelumnya akan berusaha diperbaiki di dalam tulisan ini.

\section{TEORI DAN METODE}

Para ahli bersepakat mengatakan bahwa persoalan pokok yang dibicarakan dalam proses morfofonemik adalah perubahan fonem yang terjadi sebagai akibat persinggungan morfem dengan morfem. Dalam pada itu, perbedaan para ahli dalam menyoroti proses morfofonemik hanyalah pada pelbagai jenis penggolongan sebagai akibat yang ditimbulkan oleh persinggungan morfem-morfem itu. Perbedaan itu dipengaruhi oleh perbedaan lambang morfem yang dipilih dan kuantitas data yang diperikan tiap-tiap ahli.

Kesamaan pendapat inwal proses morfofonemik oleh para ahli itu di antaranya sebagai berikut. Ramlan (2001: 83) menerangkan bahwa proses morfofonemik mempelajari perubahanperubahan fonem yang timbul sebagai akibat pertemuan satu morfem dengan morfem lain. Selanjutnya, Alwi dkk. (2003: 31) menyatakan bahwa proses perubahan bentuk yang disyaratkan oleh jenis fonem atau morfem yang digabungkan dinamakan dengan proses morfofonemik. Kridalaksana (2007: 183) menjelaskan bahwa proses morfofonemik adalah peristiwa fonologis yang terjadi karena pertemuan morfem dengan morfem.

Senada dengan Kridalaksana, Mahsun (2007: 90) menyebutkan bahwa proses morfofonemik merupakan peristiwa fonologis yang terjadi karena pertemuan morfem dengan morfem. Selanjutnya, Samsuri (1991: 201) menye butkan bahwa proses morfofonemik sebagai studi tentang perubahan-perubahan pada fonem yang disebabkan oleh hubungan dua morfem atau lebih. Sementara Parera (2010: 30) menyebutkan bahwa morfofonemik sebagai gejala yang menunjukkan hubungan bentuk antara morfem dengan fonem. Dengan demikian, para ahli bersepakat terkait fokus yang dibahas dalam proses morfofonemik, yakni perubahan dan penyesuaian fonem akibat dari persinggungan morfem.

Pada dasarnya, penelitian ini mengadopsi pengklasifikasian afiks oleh Mahsun (1990). Pengklasifikasian lambang morfem beserta seIuruh wujud konkretnya (alomorf) dalam tulisan ini didasarkan pada korelasi bentuk dan makna. Hal ini dilakukan agar pengklasifikasian morfem dapat dipertanggungjawabkan. Morfem-morfem berikut morf-morf yang bermakna sama merupakan anggota dari sebuah lambang morfem. Perbedaan bentuk morf sebagai keunikan yang dibahas di atas diterangkan kaidahnya secara khusus.

Data yang disampaikan dalam penelitian ini memanfaatkan data studi pustaka. Data studi pustaka diambil dari penelitian yang telah dilakukan sebelumnya dengan merekam dan mencatat sesuai kebutuhan. Selain itu, pemunculan data juga menggunakan metode introspektif yakni memanfaatkan intuisi kebahasaan peneliti terhadap bahasa yang dikuasainya (bahasa ibunya) untuk menyediakan data yang diperlukan bagi analisis sesuai dengan tujuan penelitian (Mahsun, 2007: 104).

Tahapan analisis data menggunakan teknik lanjutan hubung-banding menyamakan dan hubung-banding membedakan yang terdapat dalam metode padan intralingual. Teknik ini menghubung-bandingkan unsur-unsur yang bersifat lingual, baik yang terdapat dalam satu bahasa maupun dalam beberapa bahasa yang berbeda (periksa Mahsun, 2007: 117-118). $\mathrm{Hal}$ ini dimaksudkan untuk menemukan beberapa kaidah yang sama atau berbeda dari data yang dianalisis. 
Metode yang digunakan dalam penyajian hasil analisis data adalah metode informal dan metode formal. Metode informal merupakan metode yang menyajikan kaidah-kaidah hasil analisis dengan menggunakan kata-kata biasa, sedangkan metode formal merupakan metode yang menyajikan hasil analisis data dengan menggunakan lambang-lambang (M ahsun, 2007: 123).

\section{HASIL DAN PEMBAHASAN}

Sebelum menguraikan kaidah proses morfofonemik tiap-tiap morfem afiks dalam BSDSB, terlebih dahulu dijelaskan beberapa hal sebagai berikut. Pertama, penentuan klasifikasi morfem afiks didasarkan pada korelasi antara bentuk dan makna. Maksudnya, morfem afiks yang memiliki makna yang sama meskipun memiliki bentuk yang berbeda digolongkan ke dalam satu morfem afiks yang sama. Kedua, datadata yang disampaikan dalam tulisan ini bersifat mewakili untuk kepentingan penggambaran kaidah morfofonemik yang menjadi fokus penelitian.

\subsection{Proses Morfofonemik Morfem \{ba-\}}

Morfem $\{b a-\}$ memiliki empat wujud konkret, yaitu \{ba-\}, \{bar-\}, \{bal-\}, dan \{ra-\}. Keseluruhan wujud konkret tersebut membentuk verba intransitif yang bermakna perbuatan yang dilakukan oleh argumen yang mengisi fungsi subjek.

a. Morfem $\{b a-\}$ berwujud konkret $\{b a-\}$ apabila melekat pada bentuk dasar yang berfonem awal konsonan / $\mathrm{d}, \mathrm{l} / \mathrm{d} / \mathrm{,} / \mathrm{g} / \mathrm{l}$ / $\mathrm{j} /, / \mathrm{k} /, / \mathrm{l} / \mathrm{,} / \mathrm{r} / \mathrm{,} / \mathrm{s} /$, dan / t/ . Setiap fonem awal yang dilekati oleh prefiks $\{b a-\}$ mengalami pengekalan. Pengekalan yang dimaksud terjadi akibat titik artikulasi prefiks $\{b a-\}$ yang tidak homorgan dengan titik artikulasi beberapa fonem awal bentuk dasar yang dilekatinya.

$\{\mathrm{ba}-\}+$ / cukur/ 'cukur' menjadi / bacukur/ 'bercukur' $\{b a-\}+$ / cila/ 'celak' menjadi

/ bacila/ 'bercelak'

$\{$ ba- $\}+$ / dompas/ 'tombak' menjadi

/ badompas/ 'berburu'

$\{b a-\}+$ / guru/ 'guru' menjadi

/ baguru/ 'berguru'

$\{$ ba- $\}+$ / jaga/ 'jaga' menjadi

/ bajaga/ 'berjaga'

$\{b a-\}+/$ keban/ 'kebun' menjadi

/ bakeban/ 'berkebun'

$\{b a-\}+/$ kati/ 'ejek' menjadi

/ bakati/ 'bercanda'

$\{b a-\}+$ / langan/ 'jalan' menjadi

/ balangan/ 'berjalan'

$\{\mathrm{ba}-\}+$ / surak/ 'sorak' menjadi

/ basurak/ 'bersorak'

$\{b a-\}+$ / tutir/ 'cerita' menjadi

/ batutir/ 'bercerita'

b. Morfem $\{b a-\}$ berwujud konkret $\{b a r-\}$ apabila melekat dengan bentuk dasar yang berfonem awal vokal seperti / a/ , / i/ , / u/ , / e/ , dan / o/ serta fonem awal bentuk dasar mengalami pengekalan.

$\{$ ba- $\}$ + / apan/ 'kejar' menjadi

/ barapan/ 'berkejaran'

$\{$ ba- $\}+$ / iak/ 'nafas' menjadi

/ bariak/ 'bernafas'

$\{\mathrm{ba}-\}+$ / untung/ 'undang' menjadi

/ baruntung/ 'beruntung'

$\{$ ba- $\}$ + / enti/ 'pegang' menjadi

/ barenti/ 'berpegang'

$\{$ ba- $\}+$ / entok/ 'jaga' menjadi

/ barentok/ 'berjaga'

$\{$ ba- $\}+$ / odak/ 'lulur' menjadi

/ barodak/ 'berlulur'

c. Morfem \{ba- \}secara khusus berwujud konkret \{bal-\} apabila melekat dengan bentuk dasar yang berfonem awal / a/ seperti pada bentuk dasar / ajar/ serta fonem awal mengalami pengekalan. Kenyataan ini sama dengan yang terdapat di dalam bahasa Indonesia.

$\{b a-\}+/$ ajar/ 'ajar' menjadi

/ balajar/ 'belajar' 
d. Morfem \{ba- $\}$ berwujud konkret \{ra- $\}$ apabila melekat dengan bentuk dasar yang berfonem awal / b/ , / m/ , / p/, dan / y/ serta setiap fonem awal bentuk dasar mengalami pengekalan. Pengekalan yang dimaksud terjadi akibat titik artikulasi prefiks \{ra- $\}$ tidak homorgan dengan titik artikulasi beberapa fonem awal bentuk dasar yang dilekatinya. Kemunculan \{ra- $\}$ sebagai morf dari morfem \{ba-\}terjadi akibat fonem awal bentuk dasar seperti / b/ , / m/ , / p/ , dan / y/ tidak dapat dilekati oleh morfem ba- $\}$.

$$
\begin{gathered}
\{\text { ra- }\}+\text { / beda/ 'bedak' menjadi } \\
\text { / rabeda/ 'berbedak' } \\
\{\text { ra- }\}+\text { / bagi/ 'bagi' menjadi } \\
\text { / rabagi/ 'berbagi' } \\
\{\text { ra- }\}+\text { / medo/ 'obat' menjadi } \\
\text { / ramedo/ 'berobat' } \\
\{\text { ra- }\}+\text { / manjeng/ 'pacar' menjadi } \\
\text { / ramanjeng/ 'berpacaran' } \\
\{\text { ra- }\}+\text { / pina/ 'pindah' menjadi } \\
\text { / rapina/ 'berpindah' } \\
\{\text { ra- }\}+\text { / ngalik/ 'liar' menjadi } \\
\text { / rangalik/ 'berkeliaran' }
\end{gathered}
$$

\subsection{Proses Morfofonemik Morfem $\{$ raN- $\}$}

Morfem \{raN - $\}$ memiliki empat wujud konkret berupa $\{r a n-\},\{r a m-\},\{r a \eta-\}$, dan $\{r a n ̃-\}$. Keseluruhan wujud konkret tersebut membentuk adjektiva dengan makna selalu/ suka melakukan sesuatu yang disebutkan pada bentuk dasarnya.

a. Morfem \{raN- $\}$ berwujud konkret $\{r a n-\}$ apabila melekat dengan bentuk dasar yang berfonem awal / t/ . Hal ini disebabkan oleh fonem / $t$ / dengan fonem / $\mathrm{n}$ / berada pada titik artikulasi yang homorgan yaitu dental .

$$
\begin{gathered}
\{\text { ra- }\}+\text { / turit/ 'ikut' menjadi } \\
\text { / ranurit/ 'suka ikut-ikutan' } \\
\{\text { ra- }\}+\text { / tilik/ 'intip' menjadi } \\
\text { / ranilik/ 'suka mengintip' } \\
\{\text { ra- }\}+\text { / tagi/ 'tagih' menjadi } \\
\text { / ranagi/ 'suka menagih' }
\end{gathered}
$$

b. Morfem \{raN - $\}$ berwujud konkret $\{r a m-\}$ apabila melekat dengan bentuk dasar yang berfonem awal / b/ dan / p/. Hal ini disebabkan oleh fonem / b/ dan / p/ dengan fonem / $\mathrm{m}$ / berada pada titik artikulasi yang homorgan, yaitu bunyi nasal bilabial.

$$
\begin{gathered}
\{\text { ra- }\}+\text { / buya/ 'cari' menjadi } \\
\text { / ramuya/ 'suka mencari' } \\
\{\text { ra- }\}+\text { / pikir/ 'pikir' menjadi } \\
\text { / ramikir/ 'suka berpikir' } \\
\{\text { ra- }\}+\text { / pukil/ 'pukul' menjadi } \\
\text { / ramukil/ 'suka memukul' }
\end{gathered}
$$

c. Morfem \{raN- $\}$ berwujud konkret $\{r a K-\}$ apabila melekat dengan bentuk dasar yang berfonem awal / a/ , / e/ , dan / k/ serta setiap fonem awal bentuk dasar mengalami pengekalan.

$\{$ ra- $\}$ + / amuk/ 'marah' menjadi / rangamuk/ 'suka marah'

$\{r a-\}+$ / apan/ 'kejar' menjadi / rangapan/ 'suka mengejar'

$\{r a-\}+$ / ejek/ 'ejek' menjadi / rangejek/ 'suka mengejek'

$\{r a-\}+/$ konye/ 'cerewet' menjadi / rangkonye/ 'suka cerewet'

d. Morfem \{raN - $\}$ berwujud konkret $\{$ rañ-\} apabila melekat dengan bentuk dasar yang berfonem awal / s/ serta setiap fonem awal bentuk dasar mengalami peluluhan. $\mathrm{Hal}$ ini disebabkan oleh fonem / s/ dan / ny/ berada pada titik artikulasi yang homorgan yaitu nasal medio palatal.

$\{$ ra- $\}+$ / samung/ 'jawab' menjadi / ranyamung/ 'suka menjawab'

$\{$ ra- $\}+$ / suru/ 'suruh' menjadi

/ ranyuru/ 'suka menyuruh'

\subsection{Proses M orfofonemik M orfem \{ka-\}}

Morfem \{ka-\}hanya memiliki sebuah wujud konket, yaitu \{ka-\}. Morfem ini membentuk nomina dengan makna perihal yang disebutkan pada bentuk dasar yang dilekatinya.

a. Morfem $\{k a-\}$ berwujud konkret $\{k a-\}$ apabila melekat dengan bentuk dasar yang 
berfonem awal / b/ , / / , / r/ , dan / s/ , serta setiap fonem awal bentuk dasar mengalami pengekalan. Pengekalan terjadi akibat titik artikulasi prefiks $\{k a-\}$ tidak homorgan dengan titik artikulasi fonem awal bentuk dasar yang dilekatinya. Morfem $\{k a-\}$ berwujud $\{k a-\}$ hanya ditemukan pada bentuk dasar berupa adjektiva atau sifat.

$$
\begin{gathered}
\{k a-\}+\text { / balong/ 'bagus' menjadi } \\
\text { / kabalong/ 'kebaikan' } \\
\{k a-\}+\text { / lenge/ 'jelek' menjadi } \\
\text { / kalenge/ 'kejelekan' } \\
\{k a-\}+\text { / rango/ 'besar' menjadi } \\
\text { / karango/ 'kebesaran' } \\
\{k a-\}+\text { / sugi / 'kaya' menjadi } \\
\text { / kasugi/ 'kekayaan' }
\end{gathered}
$$

\subsection{Proses Morfofonemik Morfem $\{k a N-\}$}

Morfem \{kaN - \}memiliki tujuh wujud konkret, yaitu $\{k a-\},\{k a \eta-\},\{k a m-\},\{k a n-\},\{k a n ̃-\}$, $\{k a \eta$ - $\}$, dan \{gan-\}. Keseluruhan wujud konkret morfem ini membentuk verba pasif yang bermakna adversatif.

a. Morfem $\{k a \mathrm{~N}$ - $\}$ berwujud konkret $\{k a-\}$ apabila melekat dengan bentuk dasar yang berfonem awal / b/ , / m/ , / p/ , / r/ , / s/ , / $\mathrm{t} /$, / $\tilde{n} /$ dan / $\mathrm{y} /$ serta setiap fonem awal bentuk dasar mengalami pengekalan. Pengekalan terjadi akibat titik artikulasi prefiks $\{k a-\}$ tidak homorgan dengan titik artikulasi beberapa fonem awal bentuk dasar yang dilekatinya.

$\{k a-\}$ + / balik/ 'balik' menjadi

/ kabalik/ 'terbalik'

$\{k a-\}+$ / mate/ 'mati' menjadi

/ kamate/ 'kesemutan'

$\{k a-\}+$ / pantak/ 'henti' menjadi

/ kapantak/ 'terhenti'

$\{k a-\}+/$ rupat/ 'kotor' menjadi

/ karupat/ 'merasa kotor'

$\{k a-\}+$ / santil/ 'sandung' menjadi

/ kasantil/ 'tersandung'

$\{k a-\}+$ / takit/ 'takut' menjadi

/ katakit/ 'merasa takut' $\{k a-\}+/$ nyaman/ 'nyaman' menjadi / kanyaman/ 'merasa nyaman'

$\{k a-\}+$ / ngomang/ 'apung' menjadi

/ kangomang/ 'terapung'

b. Morfem $\{k a N$ - $\}$ berwujud konkret $\{k a \eta$ - $\}$ apabila melekat dengan bentuk dasar yang berfonem awal vokal seperti / a/ ,/ i/ , dan / u/ serta setiap fonem awal bentuk dasar mengalami pengekalan.

$\{k a-\}$ + / ano/ 'siang' menjadi

/ kangano/ 'terkena matahari'

$\{k a-\}+$ / angin/ 'angin' menjadi

/ kangangin/ 'terkena angin'

$\{k a-\}+$ / ila/ 'malu' menjadi

/ kangila/ 'merasa malu'

$\{k a-\}+/$ ujan/ 'hujan' menjadi

/ kangujan/ 'kehujanan'

c. Morfem $\{k a N$ - $\}$ berwujud konkret $\{k a m-\}$ apabila melekat dengan bentuk dasar yang berfonem awal / b/ serta fonem awal mengalami peluluhan. $\mathrm{Hal}$ ini disebabkan oleh fonem / b/ dengan fonem / m/ berada pada titik artikulasi yang homorgan yaitu nasal bilabial. Uniknya, data ini merupakan data satu-satunya yang dapat ditemukan dalam BSDSB.

$\{k a-\}$ + / baeng/ 'milik' menjadi

/ kamaeng/ 'merasa memiliki'

d. Morfem $\{k a N$ - $\}$ berwujud konkret $\{k a n-\}$ apabila melekat dengan bentuk dasar yang berfonem awal / d/ serta fonem awal bentuk dasar mengalami peluluhan. $\mathrm{Hal}$ ini disebabkan oleh fonem / $d$ / dengan fonem / $\mathrm{n}$ / berada pada titik artikulasi yang homorgan yaitu dental.

$\{k a-\}+$ / dapat/ 'dapat' menjadi

/ kanapat/ 'kedapatan'

e. Morfem $\{k a N$ - $\}$ berwujud konkret $\{k a n ̃-\}$ apabila melekat dengan bentuk dasar yang berfonem awal / j/ serta fonem awal mengalami peluluhan. $\mathrm{Hal}$ ini disebabkan oleh fonem / j/ dengan fonem / ñ berada pada titik artikulasi yang homorgan yaitu 
medio palatal. Bentuk ini juga merupakan bentuk satu-satunya dalam kalangan penutur BSDSB.

$\{k a-\}+$ / jerang/ 'jera' menjadi

/ kanyerang/ 'merasa trauma'

f. Morfem $\{k a N-\}$ berwujud konkret $\{k a K Y-\}$ apabila melekat dengan bentuk dasar yang bersilabel satu serta fonem awal bentuk dasar mengalami pengekalan.

$\{k a-\}+$ / nyin/ 'goyang' menjadi / kangenyin/ 'terguncang'

$\{k a-\}+$ / nat/ 'tindih' menjadi / kangenat/ 'tertindih'

g. Morfem $\{k a N$ - $\}$ berwujud konkret \{gan- $\}$ apabila melekat dengan bentuk dasar yang berfonem awal / t/ , dan jumlahnya sangat terbatas serta fonem awal bentuk dasar mengalami pengekalan. Hal ini disebabkan oleh fonem / $\mathrm{n}$ / dan / $\mathrm{t} /$ berada di titik artikulasi yang homorgan yaitu dental.

\{gan- $\}+$ / tuna/ 'tak guna' menjadi

/ gantuna/ 'merasa tak berguna' \{gan-\}+/ teri/ 'jatuh' menjadi

/ ganteri/ 'menderita keguguran'

\subsection{Proses Morfofonemik Morfem $\{$ saN- $\}$}

Morfem \{saN - $\}$ memiliki lima wujud konkret berupa $\{$ sa- $\},\{$ sam- $\},\{$ san- $\},\{$ sa $\eta-\}$, dan \{sayə-\}. Keseluruhan wujud konkret tersebut membentuk verba aktif transitif dengan makna tindakan.

a. Morfem \{saN-\} berwujud konkret $\{$ sa- $\}$ apabila melekat dengan bentuk dasar yang berfonem awal / b/ , / d/ , / g/ , / k/ , / / , / $\mathrm{m} /$, / p/ , / r/ , / s/ , / t/ , / ñ , dan / y/ , serta setiap fonem awal bentuk dasar tersebut mengalami pengekalan. Pengekalan yang dimaksud terjadi akibat titik artikulasi prefiks \{sa-\} tidak homorgan dengan titik artikulasi beberapa fonem awal bentuk dasar yang dilekatinya, kecuali fonem / s/ . $\{$ sa- $\}+$ / balong/ 'bagus' menjadi / sabalong/ 'memperbaiki'
$\{$ sa- $\}+$ / dunung/ 'dulu' menjadi / sadunung/ 'mendahulukan'

$\{$ sa- $\}$ + / gera/ 'cantik' menjadi / sagera/ 'mempercantik'

$\{$ sa- $\}+$ / kurang/ 'kurang' menjadi / sakurang/ 'mengurangi'

$\{$ sa- $\}$ + / lesik/ 'kotor' menjadi / salesik/ 'mengotori'

$\{$ sa- $\}+$ / mate/ 'mati' menjadi / samate/ 'membunuh'

$\{$ sa- $\}$ + / pene/ 'pendek' menjadi

/ sapene/ 'memendekkan'

$\{$ sa- $\}+$ / rungan/ 'kabar' menjadi / sarungan/ 'mengabarkan'

$\{$ sa- $\}$ + / rusak/ 'rusak' menjadi / sarusak/ 'merusakkan'

$\{$ sa- $\}$ + / sai/ 'satu' menjadi

/ sasai/ 'menyatukan'

$\{$ sa- $\}+$ / tingi/ 'tinggi' menjadi / satingi/ 'mempertinggi'

$\{$ sa- $\}$ + / nyaman/ 'nyaman' menjadi / sanyaman/ 'menyamankan' $\{$ sa- $\}$ + / ngantang/ 'berhenti' menjadi / sangantang/ 'menghentikan'

b. Morfem \{saN - $\}$ berwujud konkret $\{$ sam- $\}$ apabila melekat dengan bentuk dasar yang berfonem awal / b/ sehingga fonem awal bentuk dasar mengalami peluluhan. $\mathrm{Hal}$ ini disebabkan oleh fonem / b/ dengan fonem / $\mathrm{m}$ / berada pada titik artikulasi yang homorgan yaitu nasal bilabial.

$\{$ sa- $\}$ + / balik/ 'balik' menjadi

/ samalik/ 'mengembalikan'

$\{$ sa- $\}+$ / bolang/ 'buang' menjadi

/ samolang/ 'membuang'

c. Morfem $\{$ saN - $\}$ berwujud konkret $\{$ san- $\}$ apabila melekat dengan bentuk dasar yang berfonem awal / d/ dan / t/ sehingga setiap fonem awal bentuk dasar mengalami peluluhan. Hal ini disebabkan oleh fonem / d/ dan / t/ dengan fonem / n/ berada pada titik artikulasi yang homorgan yaitu apiko dental. 
$\{$ sa- $\}+$ / dapat/ 'dapat' menjadi / sanapat/ 'menyampaikan'

$\{$ sa- $\}+$ / datang/ 'datang' menjadi / sanatang/ 'mendatangkan'

$\{$ sa- $\}$ + / depat/ 'tindih' menjadi / sanepat/ 'menindihkan'

$\{$ sa- $\}+$ / turit/ 'ikut' menjadi / santurit/ 'menuruti'

d. Morfem $\{\mathrm{saN}$ - $\}$ berwujud konkret $\{\mathrm{sa} \eta$ - $\}$ apabila melekat dengan bentuk dasar yang berfonem awal vokal seperti / a/ , / i/ , / e/ , dan / o/ sehingga fonem awal bentuk dasar mengalami pengekalan.

$\{$ sa- $\}$ + / ampas/ 'banting' menjadi / sangampas/ 'membanting'

$\{$ sa- $\}+$ / ilang/ 'hilang' menjadi / sangilang/ 'menghilangkan'

$\{$ sa- $\}+$ / enti/ 'pegang' menjadi / sangenti/ 'menggadaikan'

$\{$ sa- $\}$ + / ompa/ 'capek' menjadi / sangompa/ 'melelahkan'

e. Morfem $\{\mathrm{saN}-\}$ berwujud konkret $\{$ say $\mathrm{s}-\}$ apabila melekat dengan bentuk dasar yang bersilabel satu sehinggafonem awal bentuk dasar mengalami pengekalan.

$\{$ sa- $\}+$ / pas/ 'pas' menjadi

/ sangepas/ 'mengepaskan'

$\{$ sa- $\}+$ / rat/ 'erat' menjadi / sangerat/ 'mengeratkan'

$\{$ sa- $\}+$ / rup/ 'teduh' menjadi

/ sangerup/ 'meneduhkan'

\subsection{Proses Morfofonemik Morfem \{sa-\}}

Morfem \{sa-\} hanya memiliki satu wujud konkret, yakni \{sa-\}dengan makna sebuah atau satu kumpulan yang tersebut pada bentuk dasar yang dilekatinya.

a. Morfem \{sa- $\}$ berwujud konkret $\{$ sa- $\}$ apabila melekat dengan bentuk dasar nomina yang menyatakan jumlah.

$$
\begin{gathered}
\{\text { sa- }\}+\text { / desa/ 'desa' menjadi } \\
\text { / sadesa/ 'sedesa' } \\
\{\text { sa- }\}+\text { / kilo/ 'kilo' menjadi } \\
\text { / sakilo/ 'sekilo' }
\end{gathered}
$$

\subsection{Proses Morfofonemik Morfem \{pa-\}}

Morfem \{pa- $\}$ hanya memiliki wujud konkret berupa \{pa-\}. Morfem ini membentuk nomina dengan makna perihal yang disebutkan pada bentuk dasarnya.

a. Morfem \{pa-\} berwujud konkret \{paapabila melekat dengan bentuk dasar yang berfonem awal / l/ , / m/ , dan / r/ sehingga setiap fonem awal bentuk dasar mengalami pengekalan.

$\{$ pa- $\}+$ / langan/ 'jalan' menjadi

/ palangan/ 'perjalanan'

$\{$ pa- $\}+/$ menong/ 'dengar' menjadi

/ pamenong/ 'pendengaran'

$\{$ pa- $\}+$ / mamung/ 'bau' menjadi

/ pamamung/ 'penciuman'

$\{$ pa- $\}+$ / rasa/ 'rasa' menjadi

/ parasa/ 'perasaan'

\subsection{Proses Morfofonemik Morfem \{paN-\}}

Morfem \{paN - $\}$ memiliki delapan wujud

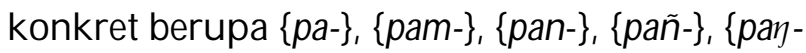

\}, \{paya-\}, \{par-\}, dan $\{$ pal- $\}$.

a. Morfem \{paN-\} berwujud konkret \{pa-\} apabila melekat dengan bentuk dasar yang berfonem awal / b/ , / k/ , dan / s/ sehingga setiap fonem awal bentuk dasar mengalami pengekalan.

$\{$ paN - $\}+/$ beli/ 'beli' menjadi

/ pabeli/ 'mas kawin'

$\{$ paN - $\}+/$ kakan/ 'makan' menjadi

/ pakakan/ 'makanan'

$\{$ paN - $\}+/$ lemar/ 'pikul' menjadi

/ palemar/ 'pikulan'

$\{$ paN - $\}+/$ loat/ 'iris' menjadi

/ paloat/ 'irisan'

$\{$ paN - $\}+/$ lili/ 'ganti' menjadi

/ palili/ 'pengganti'

$\{$ paN - $\}+/$ mela/ 'bibit' menjadi

/ pamela/ 'pecahan kaca'

$\{\mathrm{paN}-\}+/$ rayu/ 'rayu' menjadi

/ parayu/ 'rayuan'

$\{$ paN - $\}+/$ rantak/ 'potong' menjadi

/ parantak/ 'talenan' 
$\{$ paN - $\}+$ / suru/ 'suruh' menjadi

\section{/ pasuru/ 'pesuruh'}

b. Morfem \{paN - $\}$ berwujud konkret \{pam- $\}$ apabila melekat dengan bentuk dasar yang berfonem awal / b/ dan / p/ sehingga fonem awal bentuk dasar mengalami peluluhan. Hal ini disebabkan oleh fonem / b/ dan / p/ dengan fonem / m/ berada pada titik artikulasi yang homorgan yaitu nasal bilabial.

$\{\mathrm{paN}-\}+$ / buya/ 'cari' menjadi

/ pamuya/ 'mata pencaharian'

$\{$ paN -$\}+/$ beang/ 'beri' menjadi

/ pameang/ 'berian'

$\{$ paN -$\}+/$ beri/ 'suka' menjadi

/ pameri/ 'kegemaran'

$\{$ paN -$\}+/$ beli/ 'beli' menjadi

/ pameli/ 'belanjaan'

$\{$ paN - $\}+/$ polak/ 'patah' menjadi

/ pamolak/ 'patahan'

$\{$ paN - $\}+$ / pukil/ 'pukul' menjadi

/ pamukil/ 'pukulan'

$\{$ paN- $\}+/$ puji/ 'puji' menjadi

/ pamuji/ 'pujian'

$\{\mathrm{paN}-\}+/$ popo/ 'cuci' menjadi

/ pamopo/ 'cucian'

c. Morfem \{paN-\} berwujud konkret \{pan-\} apabila melekat dengan bentuk dasar yang berfonem awal / $t /$ sehingga fonem awal bentuk dasar mengalami peluluhan. Hal ini disebabkan oleh fonem / t/ dengan fonem / n/ berada pada titik artikulasi yang homorgan yaitu apiko dental.

$\{\mathrm{paN}-\}+/$ totang/ 'ingat' menjadi

/ panotang/ 'ingatan'

$\{$ paN- $\}+/$ tungku/ 'sambung' menjadi

/ panungku/ 'sambungan'

$\{$ paN -$\}+/$ tali/ 'tali' menjadi

/ panali/ 'ikatan'

$\{$ paN -$\}+/$ tau/ 'duduki' menjadi

/ panau/ 'dudukan'

d. Morfem \{paN - $\}$ berwujud konkret \{pañ-\} apabila melekat dengan bentuk dasar yang berfonem awal / s/ sehingga fonem awal bentuk dasar mengalami peluluhan. $\mathrm{Hal}$ ini disebabkan oleh fonem / s/ dengan fonem / ñ/ berada pada titik artikulasi yang homorgan yakni medio palatal.

$\{$ paN -$\}+/$ sempit/ 'kirim' menjadi

/ panyempit/ 'kiriman'

$\{\mathrm{paN}-\}+/$ sayang/ 'sayang' menjadi

/ panyayang/ 'rasa sayang'

$\{$ paN - $\}+/$ sadu/ 'percaya' menjadi

/ panyadu/ 'kepercayaan'

$\{$ paN - $\}+/$ sampat/ 'tutup' menjadi

/ panyampat/ 'penutup'

e. Morfem \{paN-\} berwujud konkret $\{p a \eta-\}$ apabila melekat dengan bentuk dasar yang berfonem awal vokal seperti / a/ , / i/ , / u/ , dan / e/ sehingga fonem awal bentuk dasar mengalami pengekalan.

$\{$ paN - $\}+/$ ampar/ 'pembibitan' menjadi

/ pangampar/ 'tempat bibit'

$\{$ paN - $\}+/$ ampin/ 'ampun' menjadi

/ pangampin/ 'ampunan'

$\{$ paN -$\}+/$ ingo/ 'lihat' menjadi

/ pangingo/ 'penglihatan'

$\{$ paN - $\}+/$ udit/ 'hisap rokok' menjadi

/ pangudit/ 'perokok'

$\{$ paN -$\}+/$ eneng/ 'minta' menjadi

/ pangeneng/ 'permintaan'

f. Morfem $\{$ paN - $\}$ berwujud konkret $\{$ panə- $\}$ apabila melekat dengan bentuk dasar yang bersilabel satu.

$\{$ paN - $\}+/$ to/ 'tahu' menjadi

/ pangeto/ 'ilmu pengetahuan'

g. Morfem \{paN-\} berwujud konkret \{par-\} apabila melekat dengan bentuk dasar yang berfonem awal vokal seperti / a/ , / e/ , dan / o/ sehingga fonem awal bentuk dasar mengalami pengekalan.

$\{$ paN -$\}+/$ angan/ 'ingat' menjadi

/ parangan/ 'hayalan/ ingatan'

$\{$ paN - $\}+/$ ajak/ 'ajak' menjadi

$$
\text { / parajak/ 'ajakan' }
$$


$\{\mathrm{paN}-\}+/$ ame/ 'kunyah' menjadi

/ parame/ 'cemilan'

$\{\mathrm{paN}-\}+/$ enti/ 'pegang' menjadi

/ parenti/ 'pegangan'

$\{\mathrm{paN}-\}+/$ olas/ 'elus' menjadi

/ parolas/ 'elusan'

h. Morfem $\{\mathrm{paN}$ - $\}$ secara khusus berwujud konkret $\{\mathrm{pal}-\}$ apabila melekat dengan bentuk dasar yang berfonem awal vokal seperti / a/ pada data ajar sehingga fonem awal bentuk dasar mengalami pengekalan. $\{\mathrm{paN}-\}+/$ ajar/ 'ajar' menjadi / palajar/ 'pelajar'

\subsection{Proses Morfofonemik Morfem $\mathbb{N}$ - $\}$}

Morfem $\mathbb{N}$ - \}memiliki enam wujud konkret berupa morf $\{-\}-\{n-\},\{m-\},\{n-\},\{m a\}$, dan $\{m a r-\}$. Keseluruhan wujud konkret tersebut membentuk verba intransitif dengan makna perbuatan yang disebutkan pada bentuk dasarnya.

a. Morfem $\{\mathbb{N}$ - $\}$ berwujud konkret $\{$ - $\}$ - apabila melekat dengan bentuk dasar yang berfonem awal vokal seperti / a/ , / i/ , dan / e/ sehingga konsonan berupa / k/ dan / $\mathrm{p} /$. Bentuk dasar yang berawalan vokal, fonem awalnya mengalami pengekalan sedangkan bentuk dasar yang berawalan konsonan, fonem awalnya mengalami peluluhan. Khusus fonem / k/, luluh disebabkan oleh kesamaan titik artikulasi dengan / $\mathrm{N}-/$ yaitu dorso velar sedangkan fonem / $\mathrm{p} /$ merupakan kasus yang terjadi satu-satunya dalam BSDSB.

$\{\mathbb{N}-\}$ + / amuk/ 'marahi' menjadi / ngamuk/ 'perbuatan marah'

$\{\mathbb{N}-\}+$ / ajar/ 'ajar' menjadi / ngajar/ 'kegiatan mengajar'

$\mathbb{N}-\}+$ / inum/ 'minum' menjadi / nginum/ 'kegiatan minum'

$\{\mathbb{N}-\}+$ / ejek/ 'ejek' menjadi / ngejek/ 'perbuatan mengejek'

$\{\mathbb{N}-\}$ + / eneng/ 'minta' menjadi / ngeneng/ 'kegiatan meminta'
$\mathbb{N}-\}+$ / kejar/ 'kejar' menjadi / ngejar/ 'kegiatan mengejar'
$\{\mathbb{N}-\}+$ / pamit/ 'pamit' menjadi / ngamit/ 'perbuatan pamit'

b. Morfem $\mathbb{N}$ - \}berwujud konkret \{n- $\}$ apabila melekat dengan bentuk dasar yang berfonem awal / s/ sehingga setiap fonem awal bentuk dasar mengalami peluluhan. Terkait kasus tersebut, $\mathbb{N}$ - $\}$ mengalami proses morfofonemik berupa perubahan fonem/ segmen / s/ menjadi / ñ/ . Hal ini disebabkan oleh fonem / s/ dan / ñ merupakan fonem yang bertitik artikulasi homorgan.

$\{\mathrm{N}-\}+$ / sapu/ 'sapu' menjadi

/ nyapu/ 'kegiatan menyapu'

$\{N-\}+$ / sampe/ 'hinggap' menjadi

/ nyampe/ 'perbuatan hinggap'

$\{\mathrm{N}-\}+$ / suru/ 'suruh' menjadi

/ nyuru/ 'kegiatan menyuruh'

$\{\mathbb{N}-\}+/$ sesek/ 'tenun' menjadi

/ nyesek/ 'kegiatan menenun'

c. Morfem $\{\mathbb{N}$ - $\}$ berwujud konkret $\{\mathrm{m}$ - $\}$ apabila melekat dengan bentuk dasar yang berfonem awal / b/ dan / $p /$ sehingga fonem awal bentuk dasar mengalami peluluhan. Hal ini disebabkan oleh fonem / b/ dan / p/ dengan fonem $/ \mathrm{m} /$ berada pada titik artikulasi yang homorgan yaitu nasal bilabial.
$\{\mathrm{N}-\}+$ / beli/ 'beli' menjadi
/ meli/ 'kegiatan membeli'
$\{N-\}+/$ pukil/ 'pukul' menjadi
/ mukil/ 'perbuatan memukul'
$\{\mathbb{N}-\}+/$ pikir/ 'pikir' menjadi
/ mikir/ 'kegiatan berpikir'

d. Morfem $\mathbb{N}$ - $\}$ berwujud konkret $\{n-\}$ apabila melekat dengan bentuk dasar yang berfonem awal / $t /$ sehingga fonem awal bentuk dasar mengalami peluluhan. $\mathrm{Hal}$ ini disebabkan oleh fonem / $t$ / dengan fonem / $\mathrm{n} /$ berada pada titik artikulasi yang homorgan yaitu apiko dental.

$\{\mathbb{N}-\}+/$ tanam/ 'tanam' menjadi

/ nanam/ 'kegiatan menanam' 
$\{\mathbb{N}-\}$ + / temak/ 'tembak' menjadi / nemak/ 'kegiatan menembak'

$\{\mathbb{N}-\}+$ / tulis/ 'tulis' menjadi / nulis/ 'kegiatan menulis'

e. Morfem $\{\mathbb{N}-$ \} berwujud konkret \{ma- $\}$ apabila melekat dengan bentuk dasar yang berfonem awal / l/ dan / $r$ / sehingga setiap fonem awal bentuk dasar mengalami pengekalan. Pengekalan yang dimaksud terjadi akibat titik artikulasi prefiks \{ma-\}tidak homorgan dengan titik artikulasi beberapa fonem awal bentuk dasar yang dilekatinya. $\{\mathbb{N}-\}+$ / rau/ 'ladang' menjadi

/ marau/ 'kegiatan berladang'

$\{\mathbb{N}-\}+/$ rantak/ 'potong' menjadi

/ marantak/ 'kegiatan memotong'

$\{\mathbb{N}-\}+$ / lontak/ 'lompat' menjadi

/ malontak/ 'perbuatan melompati'

$\{\mathbb{N}-\}+/$ lenek/ 'intai' menjadi

/ malenek/ 'kegiatan mengintai'

f. Morfem $\{\mathbb{N}-\}$ berwujud konkret $\{$ mar- $\}$ apabila melekat dengan bentuk dasar yang berfonem awal / $\mathrm{u} /$ sehingga fonem awal mengalami pengekalan.

$\{$ ma- $\}+$ / uma/ 'sawah' menjadi / maruma/ 'kegiatan membajak'

\subsection{Proses M orfofonemik M orfem Infiks $\{-\mathrm{N}-\}$}

Morfem infiks $\{\mathrm{N}-\}$ memiliki dua wujud konkret berupa $\{-n-\}$ dan $\{-m-\}$. Keduanya berfungsi sebagai pemanis dalam bahasa sastra.

a. Morfem infiks $\{-\mathrm{N}$ - $\}$ berwujud konkret $\{n$ \} apabila melekat di tengah bentuk dasar yang suku kata keduanya adalah / d/ . Perubahan terjadi akibat titik artikulasi prefiks $\{-\mathrm{N}-\}$ menyesuaikan diri dengan titik artikulasi fonem yang dilekatinya. $\{-\mathrm{N}-\}+/$ seda/ 'suara' menjadi / senda/ 'suara (puitis)'

b. Morfem infiks $\{\mathrm{N}-\}$ berwujud konkret $\{\mathrm{m}$ \} apabila melekat di tengah bentuk dasar yang suku kata keduanya adalah / b/ .
Perubahan terjadi akibat titik artikulasi prefiks $\{-\mathrm{N}-\}$ menyesuaikan diri dengan titik artikulasi fonem yang dilekatinya. $\{\mathrm{N}-\}+/$ kebo/ 'kerbau' menjadi / kembo/ 'kerbau (puitis)'

\section{PENUTUP}

Berdasarkan uraian mengenai kaidah proses morfofonemik yang telah dibahas dalam bagian sebelumnya, dapat disimpulkan beberapa hal sebagai berikut.

1. Morfem afiks dalam BSDSB terdiri atas prefiks yakni \{ba-\}, \{raN -\}, \{ka-\}, \{kaN - \}, \{pa\}, \{paN \}, \{sa-\}, \{saN-\}, dan $\{\mathbb{N}-\}$ serta infiks $\{-\mathrm{N}-\}$.

2. Tiap-tiap morfem afiks memiliki beberapa wujud konkret berupa morf ketika bergabung dengan bentuk dasar melalui afiksasi: (1) prefiks \{ba-\}memiliki wujud konkret \{ba\}, \{bar-\}, \{a-\}, dan \{bal-\}; (2) prefiks \{raN - $\}$ memiliki wujud konkret \{ran-\}, \{ram-\}, \{ran\}, dan \{rañ-\}; (3) prefiks \{ka-\} memiliki wujud konkret $\{k a-\}$; (4) prefiks $\{k a N$ - $\}$ memiliki wujud konkret \{ka-\}, \{kay-\}, \{kam\}, \{kan-\}, \{kañ-\}, dan \{kayว-\}; (5) prefiks \{sa-\} memiliki wujud konkret \{sa-\}; (6) prefiks $\{$ saN - \} memiliki wujud konkret \{sa-\}, \{sam\}, \{san-\}, \{say-\}, dan \{sayz-\}; (7) prefiks \{pa-\} memiliki wujud konkret \{pa-\}; (8) prefiks $\{$ paN - \} memiliki wujud konkret \{pa-\}, \{pam\}, \{pan-\}, \{pañ-\}, \{pay-\},\{payə-\}\{par-\}, dan $\{$ pal-\}; (9) prefiks $\{\mathbb{N}-\}$ memiliki wujud konkret $\{\eta-\},\{n-\},\{m-\},\{n-\},\{m a-\}$, dan $\{$ mar\}; dan (10) Infiks $\{-\mathrm{N}-\}$ memiliki wujud konkret $\{n-\}$ dan $\{m-\}$.

Penelitian deskriptif mengenai BSDSB diakui telah banyak dilakukan utamanya penelitian yang dilakukan oleh Sumarsono dkk. (1986) dan Seken dkk. (1990). Namun, dalam uraian penelitian masih terdapat penjelasan yang belum memadai. Untuk itu, terkait penjelasan deskriptif dalam penelitian yang dimaksud perlu diteliti kembali kemudian dibanding- 
kan dengan data-data lain dengan memanfaatkan intuisi kebahasaan penutur BSDSB.

\section{DAFTAR PUSTAKA}

Alwi, Hasan dkk. 2003. Tata Bahasa Baku Bahasa Indonesia (Edisi Ketiga). Jakarta: Balai Pustaka.

Chaer, A bdul. 2008: M orfologi Bahasa Indonesia (Pendekatan Proses). Jakarta: Rineka Cipta. Hidayat, Rahmad. 2011. Proses Morfofonemik dalam Bahasa Sumbawa Dialek Sumbawa Besar. Skripsi S-1. FKIP Universitas Mataram. . 2014. “Verba Derivasional dalam Bahasa Sumbawa Dialek Sumbawa Besar. Tesis S-2 Linguistik. Fakultas IImu Budaya. Yogyakarta: UGM.

Kasman. 2002. "Morfologi dan Morfofonemik Bahasa Sumbawa Dialek Tongo". Tesis S2. Program Pascasarjana UNS. Surakarta: UNS.

Kridalaksana, Harimurti. 2007. Pembentukan Kata dalam Bahasa Indonesia. Jakarta: PT Gramedia Pustaka Utama.
Mahsun. 1990. "Morfologi Bahasa Sumbawa Dialek Jereweh". Tesis S-2 Linguistik. Fakultas IImu Budaya. Yogyakarta: UGM. . 2007. M etode Penelitian Bahasa. Tahapan Strategi, M etode, dan Tekniknya. Jakarta: PT RajaGrafindo Persada. 2007. M orfologi. Yogyakarta: Gama Media.

Parera, Jos Daniel. 2010. M orfologi Bahasa. Jakarta: PT Gramedia Pustaka Utama.

Ramlan, M. M orfologi Suatu Tinjauan D eskriptif. Yogyakarta: C.V. Karyono.

Samsuri. 1991. A nalisis Bahasa. M emahami Bahasa Secara IImiah. Jakarta: Erlangga.

Seken, I Ketut, dkk. 1990. M orfologi Bahasa Sumbawa. Jakarta: Pusat Pembinaan dan Pengembangan Bahasa Depdikbud.

Sumarsono. dkk. 1986. M orfologi dan Sintaksis Bahasa Sumbawa. Jakarta: Pusat Pembinaan dan Pengembangan Bahasa Depdikbud. 